\title{
Biorepress of fumonisin B1 production and their phytotoxicity on growth and ultrastructures of Maize (Zea mays) Seedlings
}

\author{
Al Abboud M.A. \\ Biology Department, Faculty of Science, Jazan University, Kingdom of Saudi Arabia
}

\begin{abstract}
The results clearly indicated that the seed germinibility in the presence of FB1 was decreased with increasing their concentration, whereas the germinibility was uncompletely ceased at high concentrations, a slight initial lag in germination observed at lowest concentration $28.57 \mu \mathrm{g} / \mathrm{ml}$ and highest concentration $64.11 \mu \mathrm{g}$ $/ \mathrm{ml}$, respectively compared with the control. At concentration of FB1 $(28.57 \mu \mathrm{g} / \mathrm{ml})$, elongation of the hypocotyls and epicotyls in seedlings slightly inhibited compared with the control. Chlorophyll $\mathrm{a}$ and $\mathrm{b}$ content of seedlings of Zea mays decreased with increasing concentrations of Fumonisin B1. Chlorophyll a content was $6.23,3.88$ and $3.91(\mathrm{mg} / \mathrm{g}$ fresh weight) at concentrations 28.57, 40.54 and $64.11(\mu \mathrm{g} / \mathrm{ml})$ of Fumonisin B1 compared with the control $8.55 \mathrm{mg} / \mathrm{g}$ fresh weight. The ultrastructural studies indicate that there were dramatic differences between the treated and untreated tissues of Zea mays seedlings with the toxin FB1. The treated cells with FB1 are highly vacuolated compared with the untreated cells. Thin layer of external epidermis was observed in untreated cells while thick layer of external epidermis in treated cells was appeared. Sacchaaromyces cerevisiae reduced FB1 to $40.54(\mu \mathrm{g} / \mathrm{ml})$ compared with control $64.11(\mu \mathrm{g} / \mathrm{ml})$.On the other hand Trichoderma harizianum was more efficient in FB1 productivity where productivity was reduced to $28.57(\mu \mathrm{g} / \mathrm{ml})$ with $44.56 \%$.
\end{abstract}

Keywords: Biorepress, fumonisin B1, phytotoxicity, ultrastructures

\section{INTRODUCTION}

Maize (Zea mays L.) is a cereal crop grown throughout the word. Maize plays an important role in the diet of millions of people due to its high yields per hectare, its ease of cultivation and adaptability to different agro-ecological zones, versatile food uses and storage characteristics (Asiedu, 1989). Kossou and Aho (1993) reported that fungi could cause about $50-80 \%$ of damage on farmer's maize during the storage period if conditions are favorable for their development. The major genera commonly encountered on maize in tropical regions are Fusarium, Aspergillus and Penicillium (Orsi et al., 2000). Fumonisins are mycotoxins which are a structurally related group of longcarbon chain compounds (Munkvold and Desjardins 1997). Fumonisin analogues have been identified and classified into fumonisin $\mathrm{A}_{1}, \mathrm{~A}_{2}, \mathrm{~B} 1, \mathrm{~B}_{2}, \mathrm{~B}_{3}$, and $\mathrm{B}_{4}$ based on their chemical structure. Fumonisins are produced mainly by Fusarium moniliforme $(=F$. verticillioides), $F$. proliferatum, and several other Fusarium species. Fumonisin B1 (FB1) first isolated from F. moniliforme MRC 826 by Gelderblom et al. (1988), is a hydroxylated longchain alkylamine with two tricarboxylic acid moieties attached. FB1 has been reported to be phytotoxic to various weeds and crop cultivars (Abbas and Boyette 1992). Maize is the product in which fumonisins are most abundant (Shephard et al., 1996). Fumonisins can contaminate maize foods and feeds as a result of the Fusarium invasion before and after harvest (Doko et al., 1995). Fusarium species are widespread throughout the world and produce phytotoxins such as the fumonisins, 
fusaric acid, and moniliformin (Chakrabari and Basuchaudharg 1980, Duke 1986, Burmeister and Plattner 1987). Phytotoxic fumonisins are produced by $F$. moniliforme and related fusaria such as $F$. proliferatum (Ross et al. 1990, Vesonder et al. 1990, Thiel et al. 1991). Fumonisins are found to be phytotoxic. FB1 can indeed damage a wide variety of plants including maize (Lamprecht et al., 1994). Doehlert et al. (1994) showed that the presence of high levels of fumonisins in maize seeds might have deleterious effects on seedling emergence. Elongation of maize radicles was inhibited by about $75 \%$ after $48 \mathrm{~h}$ of imbibition in $100 \mu \mathrm{g} / \mathrm{g}$ of fumonisins and amylase activities in seeds significantly decreased as well. In previous studies fumonisin has been shown to cause photobleaching, necrosis, growth inhibition, and death in intact jimsonweed plants, as well as other weed and crop species (Abbas and Boyette 1992).

Transmittal of Fusarium species such as F. proliferatum, F. culmorum and $F$. graminearum are very considerable in grain store and bread wheat because these species are able to produce fatal mycotoxin like Fumonisin, zearalenon, Deoxynivalenol and Nivalenol that can be some main reasons of entanglement in different digestive cancers (Siassi, 2000). Grains contaminated by mycotoxins are unsuitable for human and animal consumption because they may cause numerous biological disturbances (Goswami and Kistler 2004). The mycotoxin produces inhibition of protein synthesis, electrolyte losses, cytoplasm convolution and disintegration of organelles (Miller and Ewen 1997). FB1 is believed to be the most toxic fuminisin leading to most severely adverse health effects in animals (Gelderblom and Abel1 998). Many kinds of cereals including corn, sorghum, rice and wheat are known to be infected by Fusarium species and produce fumonisins, particularity corn crops (Marin et al. 1995, Fang-Ming et al. 2005). F. moniliforme is a soil-borne as well as a seed-borne pathogen of corn that inhabits in the field. Therefore, infection of $F$. moniliforme can infect the roots, stalks, and kernels of corn. Generally, the fumonisin level will increase in corn products during storage as long as proper grain moisture and temperature are maintained (Musser and Plattner 1997). Fusarium species can invade corn kernels by inner route and produce fumonisins. A significant percentage of healthy-looking corn kernels contain fumonisin levels of about 1 ppm or higher (Musser and Plattner 1997, Nelson et al. 1991). When plants are contaminated by fuminisins, they could cause physiological damage, growth inhibition, and death in plants (Abbas and Ocamb 1995). When the grains are infected, the starch granules of the endosperm are extensively degraded (pitted) (Jackowiak et al. 2002) and the storage protein matrix that surround the starch granules were absent (Pekkarinen et al. 2000). The germinibility of bean, red gram, green gram and black gram seeds had vigorously reduced when soaked on culture filtrate of the toxic fungal strain (Janardhan et al. 2011).

The interaction between mycotoxin producing fungi and other microorganisms is a common phenomenon in nature that can affect fungal growth and/or production of mycotoxins (Hassan and Bullerman 1997). Lactococcus cremoris was reported to control mycotoxinogenic mould growth (Florianowicz 2001). The effect of different fermenting microorganisms on growth of a mycotoxin- producing Aspergillus nomius was assayed. Two lactic acid bacteria, L. fermentum and L. rhamnosus, and Saccharomyces cerevisiae, All three microorganisms assayed showed growth inhibition of the mycotoxin-producing Aspergillus strain (Munoz et al. 2010). Trichoderma viride, also can control 
growth of $F$. verticillioides conidia and toxin production on maize seed (Yates et al. 1999). Mausam (2007) indicated that several Trichoderma spp have proved to be effective mycoparasites. Papavizas and Lumsden (1980) demonstrated that T. harzianum is known for parasitizing the mycelium of several important plant Pathogens.

This work was aimed to study the phytotoxicity of FB1 on growth and ultrastructures of Zea mays seedlings. Also,the present study highlights the potential use of save microorganisms in the biocontrol of Fusarium and FB1 production.

\section{MATERIAL AND METHODS \\ 1. Fumonisin $B 1$ production and their producing fung}

Under sterile conditions of laminar flow cabinet, spoiled grains of Zea mays were added to solid media per Petri dish and the dishes were incubated at $27^{\circ} \mathrm{C}$ for 7 days. One dominant fungal species was isolated from spoiled grains cultured separately on Czapek's agar medium and malt extract medium incubated for 7 days at $28 \pm 2{ }^{\circ} \mathrm{C}$.The Petri dishes were then incubated at $28 \pm 2{ }^{\circ} \mathrm{C}$ for 7 days . The cover slips were removed and fixed on slides using a tiny drop of Canadabalsam, and then, the prepared slides were examined microscopically by using software for image analysis (SIS version $2.11,1996)$ at the Regional Center for Mycology and Biotechnology at AlAzhar University Cairo, Egypt, according to the current manuals Domsch et al. (1980) and John and Brett (2006) The isolated fungus was identified as Fusarium moniliforme. This fungus was cultivated on broth medium containing $20 \mathrm{gm}$ flour of Zea mays grains for 10 days at $28{ }^{\circ} \mathrm{C}$. Then the medium was extracted with chloroform : methanol $(2: 1, \mathrm{v} / \mathrm{v})$ and shaken for $30 \mathrm{~min}$ on an orbital shaker. The extract was filtered through filter paper (no. 4, Whatman,). The extract was quantitatively analyzed for FB1 by High Performance Liquid Chromatography. Sacchaaromyces cerevisiae and Trichoderma harizianum were inoculated separately with $F$. moniliforme in the same medium .After incubation period the FB1 was determined.

\section{Plant Cultivation and quantitative determination of chlorophylls}

Grains of Zea mays treated with three different concentratins of FB1 were cultivated in $15 \mathrm{~cm}$ diameter plastic pots containing $1.5 \mathrm{~kg}$ autoclaved soil and irrigated with water in a greenhouse. After 15 days of growth the morphological symptoms and Chlorophylls content were recorded. Chlorophylls content was determined according to Vernon and Seely (1966) using the following equations:

$\mathrm{mg}$ chlorophyll a $/ \mathrm{gm}$ tissue $=$

11.63 (A 665) -2.39 (A 649).

mg Chlorophyll b $/$ gm tissue $=$

2.11 (A 649) -5.18 (A 665).

Where (A), denotes the reading of the optical density.

\section{Germination and ultrastructures studies}

Ten grains of Zea mays were randomly selected, sterilized with $0.01 \%$ $\mathrm{NaOCl}$ for $1 \mathrm{~min}$ followed by $70 \%$ ethanol for $1 \mathrm{~min}$, and then washed in distilled water. and placed in a Petri dish, soaked with two different concentrations of FB1 and germinated at $25-26{ }^{\circ} \mathrm{C}$ with $50 \%-60 \%$ humidity in an incubator for $16 \mathrm{~h}$ in light followed by 8 hours in darkness. Electron microscope studies were carried out at the Regional Center for Mycology and Biotechnology, AlAzhar University, Cairo, Egypt. Epicotyl of germinating grains of Zea mays treated with two different concentrations of FB1. was cut into small pieces. Tissue samples were fixed in a solution of $1 \%$ paraformaldehyde, $\quad 0.025 \%$ glutaraldehyde and $0.01 \mathrm{M}$ phosphate buffered saline (PBS, $\mathrm{pH}$ 7.2) for 10 houres at $10{ }^{\circ} \mathrm{C}$, and then washed with the same buffer for $5 \mathrm{~h}$ at $10^{\circ} \mathrm{C}$. Then the 
buffer was removed and the samples covered with an aqueous solution of $1 \%$ osmium tetraoxide for $2 \mathrm{~h}$. After this the osmium solution was removed and the samples dehydrated by passage through a series of ethanol concentration ranging from $50 \%$ to $96 \%$. The absolute alcohol was removed and propylene oxide was added to the sample for $1 \mathrm{~h}$. The samples were put in propylene oxide and Epon 812 resin $(2: 1)$ then in pure resin for overnight, and placed in an oven at $60{ }^{\circ} \mathrm{C}$ for $48 \mathrm{~h}$. Small blocks were sectioned (50 $\mathrm{nm}$ ) using ultra microtome. The sections were stained by uranyl acetate-lead citrate $500 \mathrm{~A}$ and subsequently examined with the transmission electron microscope (C Joel Jem- 1200 EX II. Acc. Voltage $120 \mathrm{KV}$. MAG- medium).

\section{RESULTS AND DISCUSSION}

In the present study the $Z$. mays grains were treated with FB1 produced by F. moniliforme (Fig.1) at different concentrations .The results clearly indicated that the seed germinibility in the presence of FB1 was decreased with increasing concentrations whereas the germinibility was uncompletely ceased at high concentrations. The maximum amount of germination was observed on all test concentrations within 6 days. Except for a slight initial lag in germination observed at lowest concentration $(28.57 \mu \mathrm{g} / \mathrm{ml})$ and highest concentration $(64.11 \mu \mathrm{g} / \mathrm{ml})$ respectively compared with the control (grains untreated with FB1), this may be due to grains enzymes may affected by Fumnacine B1. In the present study, FB1did not inhibit the germination of $Z$. mays grains. At concentration of FB1 $(28.57 \mu \mathrm{g} / \mathrm{ml})$, elongation of the hypocotyls and epicotyls in seedlings was slightly inhibited compared with the control.

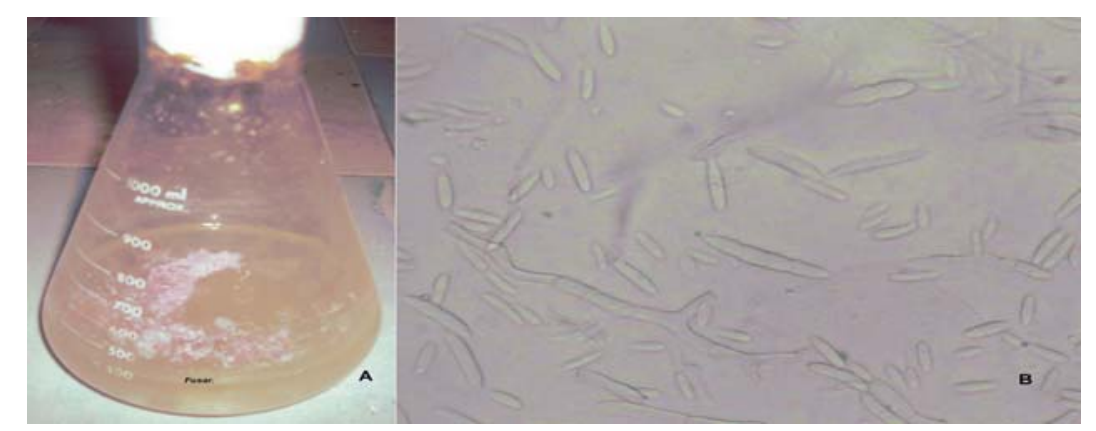

Fig. 1: F. moniliforme growth on corn flour medium (A) and their morphological characters (B).

The growth response of this cultivar of $Z$. mays to concentrations of FB1 is shown in Fig. (2). Current study is very similar to other studies where in maize, Doehlert et al. (1994) stated that FB1 is toxic to the cells but did not reduce seed germination rather, it reduced radical elongation and seed amylase production was inhibited. Decreased shoot and root lengths, shoot dry mass and reduced growth were also observed. Phytotoxic effects of FB1 were observed on seedlings growth treated with different concentrations of FB1 including growth retardation in shoot and root system, chlorosis and death of tissues (Fig. 3). The results of this study are in agreement with similar investigation done by Lamprecht et al. (1994) who reported dose-dependent reduction in shoot, root lengths and dry mass in the seedlings. The observation of Nelson et al. (1993) where FB1 caused significant stem rot was a hind sight that prompted Miller (1995) to speculate that FB1 plays a role in the pathogenicity of maize unlike other plants studied. Phytotoxicity depend on the type and concentration of mycotoxins and cultivar plant where Wakulinski (1989) stated that Trichothecenes inhibit seed germination and reduce root and shoot growth in wheat seedlings. 
The phytotoxic effects of determine the effects of aflatoxin B, on deoxynivalenol on plants can be seed germination and seedling summarized by Rocha et al. (2005) as development. Germination was not growth retardation, inhibition of seedling inhibited in any test organism at a and green plant regeneration. Nineteen concentration of $100 \mu \mathrm{g}$ of aflatoxin. plants were studied by Crisan (1973) to

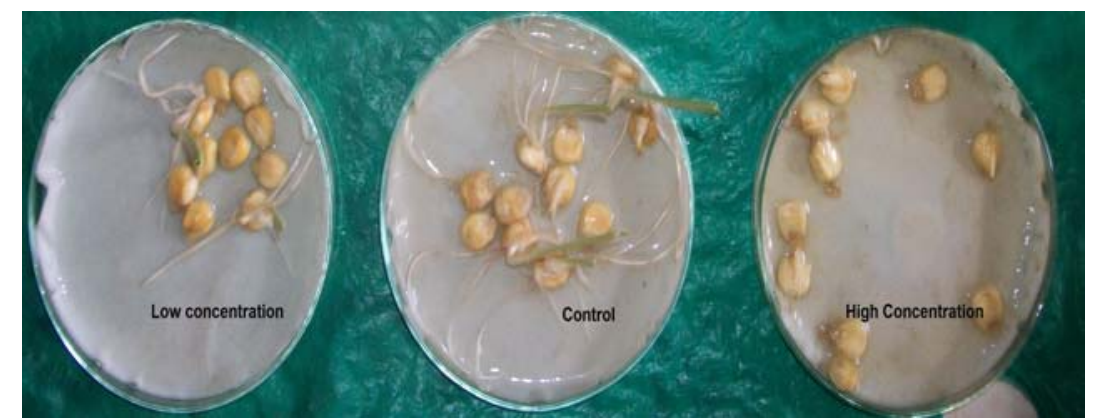

Fig. 2: Germination and growth of Z. mays seedlings in control (without FB1) and in the presence low $28.57(\mu \mathrm{g} / \mathrm{ml})$ and high $64.11(\mu \mathrm{g} / \mathrm{ml})$ concentrations of FB1.

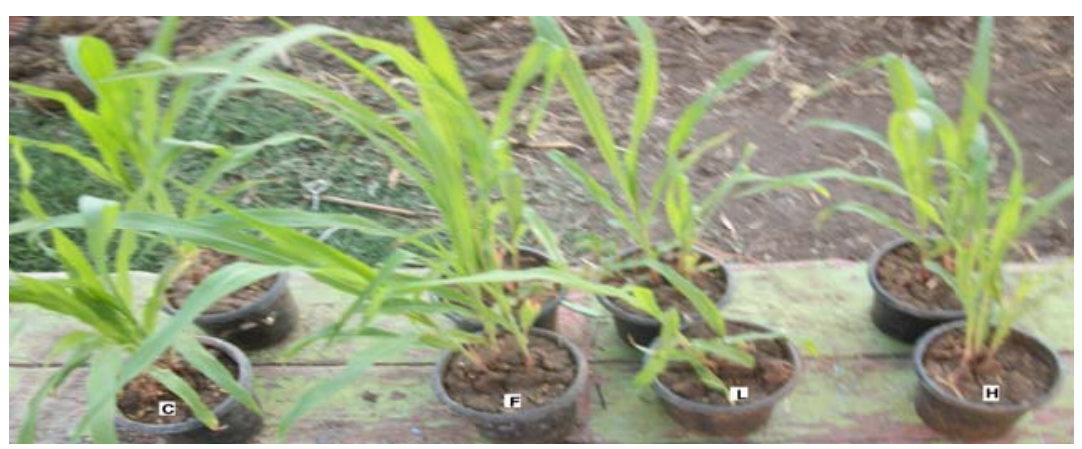

Fig. 3: Growth of seedlings of Z.mays, untreated with FB1(C) and treated with different concentrations of FB1 (F) 28.57, (L) 40.54, (H) 64.11 ( $\mu \mathrm{g} / \mathrm{ml})$.

In the present study chlorophyll a The same trial was observed with and $\mathrm{b}$ content of seedlings of Zea mays Chlorophyll b content. Several decreased with increasing concentrations investigators claimed that FB1 was of FB1 (Fig 4). Chlorophyll a content suspected to be phytotoxic and virulent. was $6.23,3.88$ and $3.91 \mathrm{mg} / \mathrm{g}$ fresh Vesonder et al. (1992) recorded that FB1 weight ) at concentrations $28.57,40.54$ and reduced chlorophyll synthesis by $59 \%$ in $64.11(\mu \mathrm{g} / \mathrm{ml})$ of FB1 compared with the duckweed (Lemman minor) fronds at $10^{-6}$ control $8.55 \mathrm{mg} / \mathrm{g}$ fresh weight of $\mathrm{M}$. seedlings of Zea mays untreated with FB1.

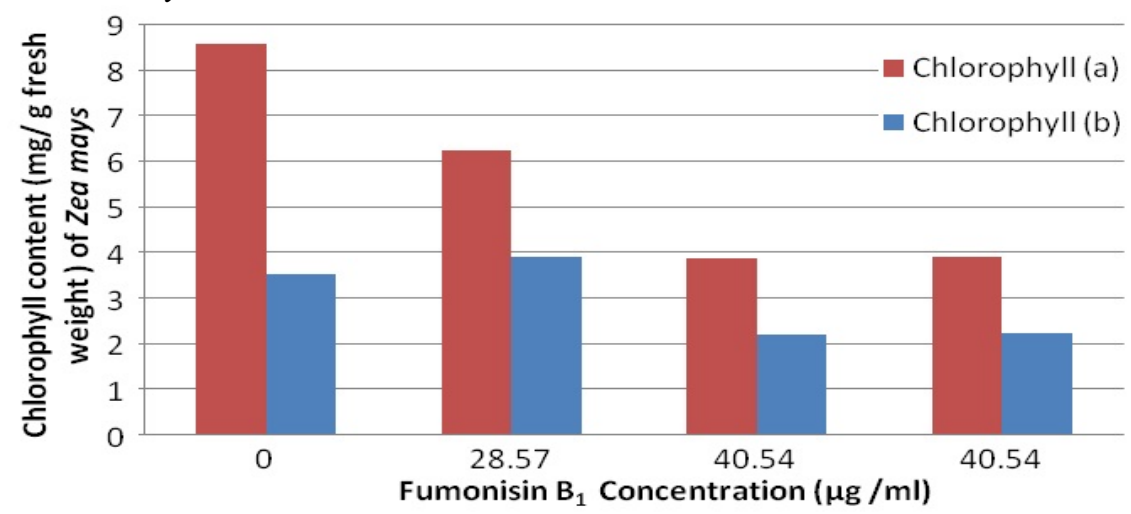

Fig. 4: Chlorophyll contents (mg/g fresh weight) of Z. mays seedlings (cultivated grains soaked with different concentrations of FB1). 
Phytotoxic properties of fumonisin have been widely studied by various authors (Doehlert et al. 1994, Kroschel and Elzein 2004, Soriano et al.2005 and Kritzinger et al. (2006)). The ultrastructural studies indicate that there were dramatic differences between the treated and nontreated tissues of
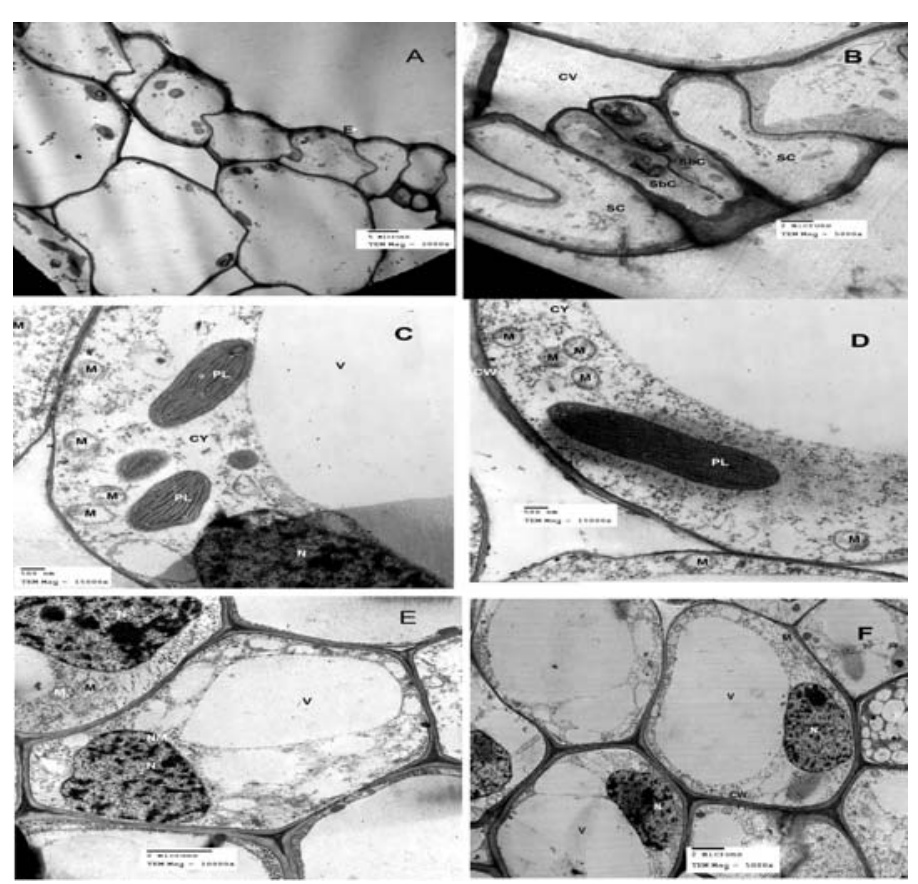

Fig. 5: Ultrastructure of untreated cells with FB1 in Z. mays. Abbreviations: $\mathrm{CW}$, cell wall; M,
mitochondria; N, nucleus; V, vacuole ; E epidermis ; SbC, subsidiary cells; SC. Guard cells;

Fig. 5: Ultrastructure of untreated cells with $\mathrm{FBl}$ in Z. mays. Abbreviations: $\mathrm{CW}$, cell wall; M,
mitochondria; N, nucleus; V, vacuole ; E, epidermis ;SbC, subsidiary cells; SC. Guard cells; PL, plastids ; CV , cavity.

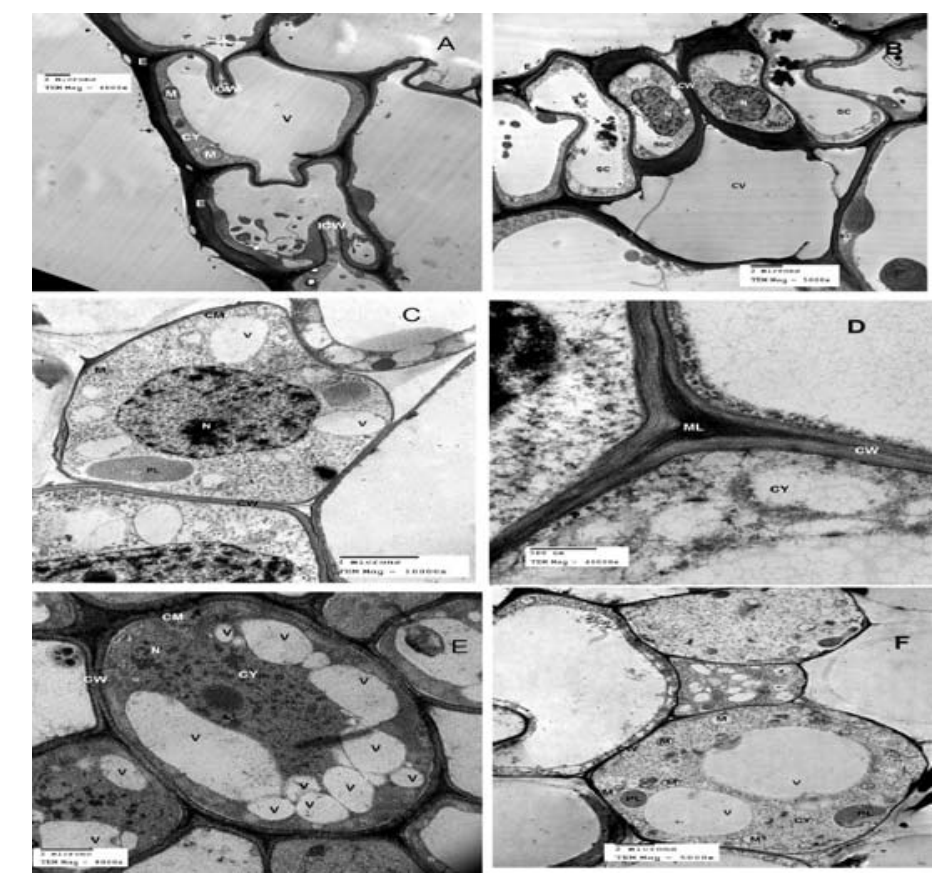

Fig. 6: Ultrastructure of treated cells in Z. mays with with FB1. Abbreviations: CW, cell wall;M, mitochondria; N, nucleus; V, vacuole ; E, epidermis ;SbC, subsidiary cells; SC. Guard cells; PL, plastids ; CV , cavity.

Zea mays seedlings with the toxin FB1 (Figs. 5 and 6). The phytotoxicity of a number of secondary metabolites present in culture filtrates of pathogenic fungi has been demonstrated (Švabová and Lebeda, 2005, Tylkowska et al 2008). 
Phytopathogenic fungi produce a wide range of phytotoxic compounds, such as AAL-toxin and FB1 (Brandwagt et al. 2001; Jackson and Taylor 1996; Stone et al. 2000). The treated cells with FB1 are highly vacuolated, where, it contain many vacuoles (Fig. $6 \mathrm{C}$ and $\mathrm{E}$ ) compared with the untreated cells, where it contain one or two vacuoles but large in size (Fig. $5 \mathrm{E}$ and F). Early studies Abbas et al. (1992) described physiological and ultrastructural effects of FB1, on jimsonweed (Datura stramonium L.). Ultrastructural damage in mesophyll palisade cells exposed FB1.

Thin layer of external epidermis (E) was observed in untreated cells (Fig. 5 A.) compared with thick layer of external epidermis ( E) in treated cells (Fig 6 A). Obvious effects began to appear as treated with FB1. The epidermal cells was most affected, in that its containing unregular cell walls (ICW) (Fig. $6 \mathrm{~A}$ ) when compared with control. From these results it can be seen that FB1 could interfere with the normal development and functioning cell wall, vacuoles, plastids and other internal organs. Kritzinger et al. (2006) noted that the irregular sizes vacuoles formed as as a result of FB1 treatment.

Stoma was clearly appeared and contained definitely subsidiary ( $\mathrm{SCb}$ ) and guard (SC) cells in treated and untreated cells ( Figs. $5 \mathrm{~A}$ and $6 \mathrm{~A}$ ) but in treated cells definitely thick wall of subsidiary cells was appeared with clearly nucleus (N). There were many polyribosomes and cytoplasmic granules in the cytoplasm $(\mathrm{CY})$ in treated and untreated cells. Clear midellamella (ML) was visible between cell walls with thickness layer especially with treated cells (Fig.6 D).Transmission electron microscopy (TEM) showed visible changes in cell ultrastructure in number and size of plastids (PL) and mitochondria $(\mathrm{M})$. The untreated cells containing many plastids and mitochondria with large size (Fig. $5 \mathrm{C}$ and D) compared with treated cells (Fig. $6 \mathrm{C}$ and F). Tylkowska et al (2008) demonstrated that ultrastructures was observed carrot roots as a result of treated with fungal toxins. Mature maize (Z. mays L.) embryos were exposed to aflatoxin B1. An ultrastructural investigation of the subcellular alterations induced following toxin exposure provided evidence of deteriorative changes in several compartments of the plant cell. (Michelle 1994). The phytotoxicity of FB1 is largely due to its effect on the disruption of sphinganine metabolism (Soriano et al. 2005) and inhibit the plasmamembrane $\mathrm{H}^{+}$ATPase from maize embryos (Kroschel and Elzein 2004).

Very few scattered reports are available on the use of yeast and fungal strains for degradation of fumonisins. $S$. cerevisiae strains were tested for their ability to degrade zearalenone and fumonisins in Sabouraud broth. Two strains were capable to degrade fumonisins partially (Styriak et al. 2001). In the present studies, biocontrol of Fusarium and reducing their productivity of FB1 was recorded (Table 1 and Fig. 7). S. cerevisiae reduced FB1 to 40.54 $(\mu \mathrm{g} / \mathrm{ml})$ compared with control $64.11(\mu \mathrm{g} / \mathrm{ml})$. On the other hand Trichoderma harizianum was more efficient in FB1 productivity where productivity was reduced to 28.57 ( $\mu \mathrm{g}$ $/ \mathrm{ml})$ with $44.56 \%$. In previous Srobarova and Eged (2005), Trichoderma was used as a biocontrol of Fusarium and their mycotoxins. Recently, Kapetanakou et al. 2012 used bacteria and yeast to reduced mycotoxins production. Yeast or yeast cell walls can also be used as adsorbents for mycotoxins. By the use of yeast cell walls only instead of whole cells, the adsorption of mycotoxins can be enhanced (Bata and La'sztity 1999). 
Table 1: Effect of S. cerevisiae and T. harizianum on FB1 production

\begin{tabular}{|l|c|c|}
\hline Treatment & Mycotoxin cocentration $(\mu \mathrm{g} / \mathrm{ml})$ & Productivity* \% \\
\hline Control & 64.11 & 100 \\
\hline S. cerevisiae & 40.54 & 63.23 \\
\hline T. harizianum & 28.57 & 44.56 \\
\hline
\end{tabular}

* Productivity $\%$ was regarded as $100 \%$ in the control

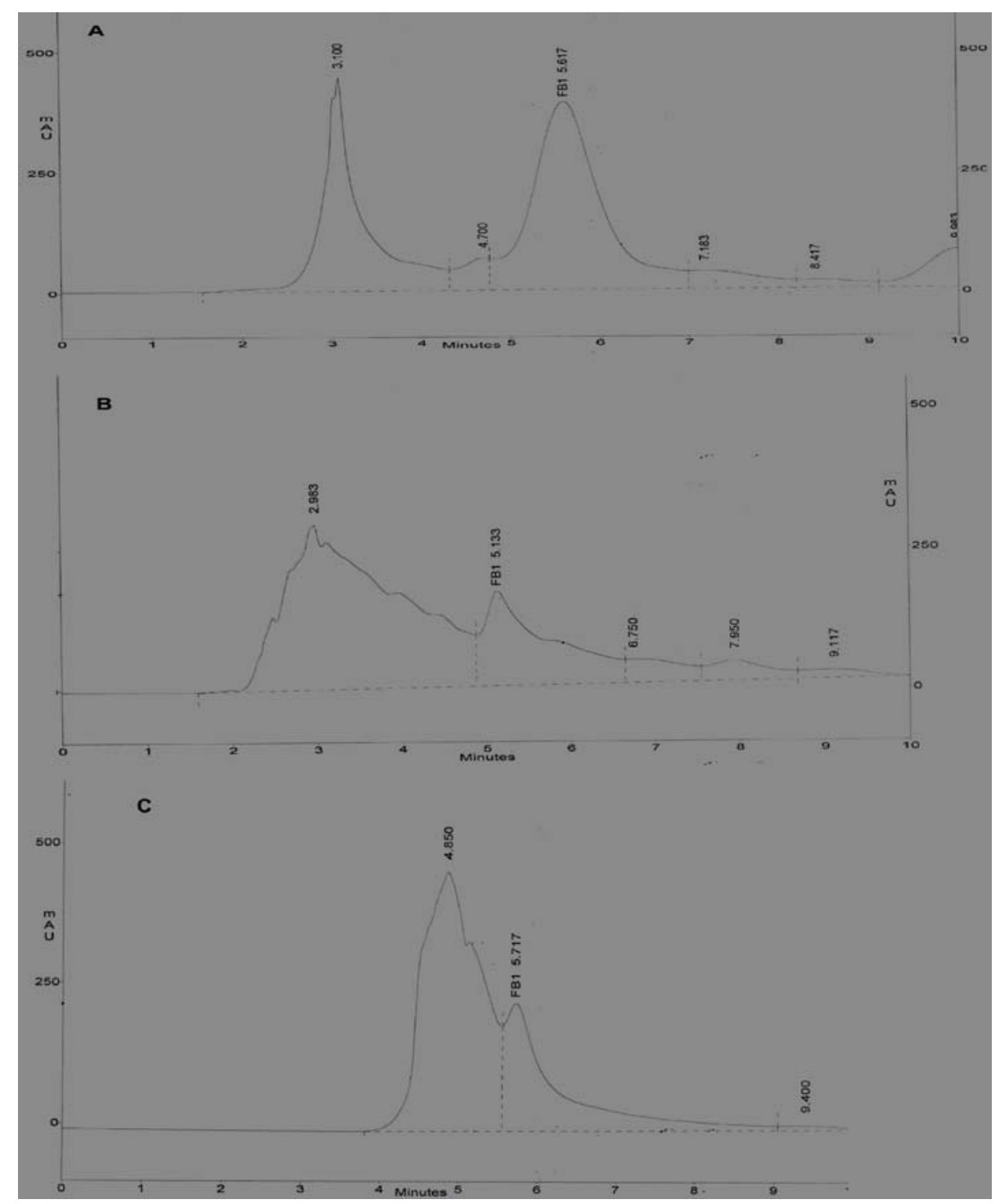

Fig. 7: HPLC chromatogram of different concentratins of FB1 in the presence of control (A), $S$. cerevisiae $(\mathrm{B})$ and T.harizianum $(\mathrm{C})$.

\section{ACKNOWLEDGEMENTS}

The author thank Dr. T. M. Abd El-

Ghany for assistance. This work was performed in the Regional Center of Mycology and Biotechnology, Al Azhar University, Cairo, Egypt.

\section{REFERENCES}

Abbas, H.K., Paul, R.N., Boyette, C.D., Duke, S.O. and Vesonder, R.F., 1992. Physiological and ultrastructural effects of fumonisin on Jimsonweed leaves. Can. J. Bot., 70: 18241833.

Abbas, H. K. and Ocamb, C. M. 1995. First report of production of fumonisin B1 by Fusarium polyphialidicum collected from seeds of pinus strobus. Plant Dis. 79: 642.

Abbas, H. K. and Boyette, C. D. 1992. Phytotoxicity of fumonisin B, on weed and crop species. Weed Technol. 40: $548-552$. 
Asiedu, J.J. (1989). Processing tropical crops. A technological approach. The Macmillan Press, London and Basingstoke. 266 p.

Bata A., La'sztity R. 1999. Detoxification of mycotoxin-contaminated food and feed by microorganisms. Trends in Food Science Technology, 10: 223-228.

Brandwagt, B. F., Kneppers, T. J., Van der Weerden, G. M., Nijkamp, H. J., and Hille, J. 2001. Most AAL toxinsensitive Nicotiana species are resistant to the tomato fungal pathogen Alternaria alternata f. sp. lycopersici. Mol. Plant-Microbe. Interact. 14: 460-470.

Burmeister, H. R., and Plattner, R. D. 1987. Enniatin production by Fusarium tricinctum and its effect on germinating wheat seeds. Phytopathology, 77: 1483 $-1487$.

Chakrabari, D. K., and Basuchaudharg, K. C. 1980. Correlation between virulence and fusaric acid production in Fusarium oxysporum f.sp. canhami. Phytopathol. Z. $90: 43-46$.

Crisan, E. V. 1973 .Effects of Aflatoxin on Seedling Growth and Ultras-tructure in Plants. Applied Microbiology, 12 (6) 991-1000.

Doehlert, D.C., Knutson, C.A., Vesonder, R.F. 1994. Phytotoxic effects of fumonisin B1 on maize seedling growth. Mycopathologia 127: 117-121.

Doko, M.B., Rapior, S., Visconti, A., Schjoth, J.E., 1995. Incidence and levels of fumonisin contamination in maize genotypes grown in Europe and Africa. J. Agric. Food Chem. 43: 429434.

Duke, S. O. 1986. Microbially produced phytotoxins as herbicides-a perspective. In The science of alJelopathy. Edited by A. R. Putnam and C. S. Tang. John Wiley \& Sons, New York. pp. 287-304.

Domsch, K.H., Gams, W. and Anderson, T. 1980. Compendium of soil fungi. Acad. Press. (London). Ltd.

Fang-Ming, L., Pei-Ching, C.,You-Min F. and Daniel,S., 2005. Determination of Fumonisin B1 and B2 in Corn Products.
Journal of Food and Drug Analysis, Vol. 13, No. 3, Pp. 273-278

Florianowicz, T. 2001. Antifungal activity of some microorganisms against Penicillium expansum. Eur. Food Res. Technol. 212: 282-286.

Gelderblom, W. C. A., Jaskiewicz, K. Marasas. W.F., Thiel, P. G., Horak, R.M.,Vleggaar.R., and Kreik, N. P. J. 1988. Fumonisins-novel mycotoxins with cancer-promoting activity produced by Fusarium moniliforme. Appl. Environ. Microbiol. 54: 1806-1811.

Gelderblom, W. C. and Abel, S. 1998. Oxidative damage and fumonisin B1induced toxicity in primary rat hepatocytes and rat liver in vivo. Toxicology 131: 121-311.

Goswami, R.S., Kistler, H.C. 2004 Heading for disaster: Fusarium graminearum on cereal crops. Mol. Plant Pathol.; 5(6): 515-525.

Jackowiak,H., Packa, D., Wiwart M., Perkowski, J., Busko, M., Borusiewicz, A. 2002. Scanning electron microscopy of mature wheat kernels infected with Fusarium culmorum. J. Appl. Genetic, 43(A): 167-176.

Jackson, A. O. and Taylor, C. B. 1996. Plant-microbe interactions: Life and death at the interface. Plant Cell, 8,1651-1668.

Janardhan, A., Subramanyam, D., Praveen, A., Reddi, M. and Narasimha G. 2011. Aflatoxin impacts on germinating seeds. Annals of Biological Research, 2 (2): 180-188.

John, F. Leslie and Brett A. Summerell, 2006. The Fusarium laboratory Manual, Blackwell Publishing Ltd.

Kapetanakou, A.E., Kollias, J.N., Drosinos, E.H., Skandamis, P.N. 2012 . Inhibition of $A$. carbonarius growth and reduction of ochratoxin A by bacteria and yeast composites of technological importance in culture media and beverages. Int $\mathrm{J}$ Food Microbiol. 16:152(3):91-9.

Kossou, D.K., Aho, N. 1993. Stockage et conservation des grains alimentaires 
tropicaux : principes et pratiques. Les Editions du Flamboyant, Benin. 125 p.

Kritzinger Q., Aveling T.A.S., van der Merwe C.F. 2006. Phytotoxic effects of fumonisin B1 on cowpea seed. Phytoparasitic, 34 (2) : 178-186.

Kroschel, J. and Elzein, A. 2002. Bioherbicidal effect of fumonisin B1, a phytotoxic metabolite naturally produced by Fusarium nygamai, on parasitic weeds of the genus striga. Biocontrol science and Technology, 14 (2) : 117-128.

Lamprecht S.C., Marasas W.F.O., Alberts J.F., Cawood M.E., Gelderblom W.C.A., Shephard G.S., Thiel P.G. and Calitz F.J., 1994. Phytotoxicity of fumonisins and TA-toxin to corn and tomato. Phytopathology, 84: 383391.

Marin, S., Snachis, V. and Magan, N. 1995. Water activity, temperature, and $\mathrm{pH}$ effects on growth of Fusarium moniliforme and Fusarium proliferatum isolates from maize. Can. J. Microbiol. 41: 1163-1170.

Mausam, V., Brar, S.K., Tyagi, R.D, Surampalli, R.Y. Valero, J.R. 2007. Antagonistic fungi, Trichoderma spp.: Panoply of biological control Biochemical Engineering J., 37: 1-20.

Michelle, M. 1994. Aflatoxin B1-induced ultrastructural alterations in mature Zea mays embryos. Mycopathologia, 128 (3): 181-192

Miller, J.D. (1995). Fungi and mycotoxins in grain: Implications for stored product research. J. Stored Prod. Res., 31:1-16.

Miller, J.D. and Ewen, M.A. 1997. Toxin effects of deoxynivalenol on ribosomes and tissues of the spring wheat cultivars Frontana and Casavant. Natural Toxins. 5:234-237.

Munkvold, G. P. and Desjardins, A. E. 1997. Fumonisins in maize - Can we reduce their occurrence? Plant Dis. 81: 556-565.

Munoz, R; Arena, M.E.; Silva, J.; Gonzalez, S.N. 2010. Inhibition of mycotoxin-producing Aspergillus nomius VSC 23 BY Lactic acid bacteria and Saccharomyces cerevisiae

.Brazilian J. Microbiol., 41: 1019-1026.

Musser, S. M. and Plattner, R. D. 1997.

Fumonisin composition in cultures of Fusarium moniliforme, Fusarium proliferatum, and Fusarium nygami. J. Agri. Food Chem. 45: 1169-1173.

Nelson, P.E., Desjardins, A.E. and Plattner, R.D., 1993. Fumonisins, mycotoxins produced by Fusarium species: Biology, Chemistry and Significance. Ann. Rev. Phytopathol., 31: 233-252.

Nelson, P. E., Plattner, R. D., Shackelford, D. D. and Desjardins, A. E. 1991. Production of fumonisins by Fusarium moniliforme strains from various substrates and geographic areas. Appl. Environ. Microbiol. 57: 2410-2412.

Nishimura, S. and Nakatsuka, S. 1993. Isolation and biological activities of two host-specific toxins from tangerine pathotype of Alternaria alternata. Phytopathology 83: 495-502.

Orsi, R.B., Correa, B., Possi, C.R., Schammass, E.A., Nogueira, J.R., Dias, S.M.C., Malozzi, M.A.B. 2000. Mycoflora and occurrence of fumonisins in freshly harvested and stored hybrid maize. J. Stor. Prod. Res. 36: $75-87$.

Papavizas, G.G. and Lumsden, R.D. 1980. Biological control of soil borne fungal propagules. Ann. Rev. Phytopathol., 18: 389-413.

Pekkarinen, A.I., Mannonen, L., Jones, B.L., Niku-Paavola, M.L. 2000. Production of proteases by Fusarium species grown on barley grains and in media containing cereal proteins. J. Cereal Sci. 31: 253-261.

Rocha, O., Ansari, K. and Doohan, F. M. 2005. Effects of trichothecene mycotoxins on eukaryotic cells: A review. Food Additives and Contaminants, 22(4): 369-378.

Ross, P. F., Nelson, P. E., Richard. J. L., Osweiler, G. D., Rice. L. G., Plattner, R. D., and Wilson, T. M. 1990. Production of fumonisins by Fusarium moniliforme and Fusarium proliferarum isolates associated with equine leukoencephalomalacia and a 
pulmonary edema syndrome in swine. Appl. Environ. Microbiol. 56: 3225-3226.

Shephard, G.S., Thiel, P.G., Stockenstrom, S., Sydenham, E.W. 1996. Worldwide survey of fumonisin contamination of corn and corn-based products. J. AOAC Int. 79: 671-687.

Siassi, F., Pouransari Z. and Ghadirian, P. 2000. Nutrition intake and esophageal cancer in the Caspian littoral of Iran: a case-control study. Cancer Detect, 24(3): 295-303.

Soriano, J.M. , Gonzalez, L. and Catala, A.I. 2005 . Mechanism of action of sphingolipids and their metabolites in the toxicity of fumonisin B1. Progress in Lipid research, 44, 345-356.

Stone, J. M., Heard, J. E., Asai, T., and Ausubel, F. M. 2000. Simulation of fungal-mediated cell death by fumonisin B1 and selection of fumonisin B1resistant arabidopsis mutants. Plant Cell 12:1811-1822.

Srobarova, A. and Eged, S. 2005 Trichoderma and sulphoethyl glucan reducemaize root rot infestation and fusaric acid content. Plant soil environ., 51(7): 322-327.

Styriak, I., Conkova, E., Kmec, V., Bohm, J., Razzazi, E. 2001. The use of yeast for microbial degradation of some selected mycotoxins. Mycotoxin Res., 17:24-27.

Svabova, L., and Lebeda, A. 2005. In Vitro selection for improved plant resistance to toxin-producing pathogens. J. of Phytopathology 153: 52-64.

Thiel, P.G., Marasas, W.F., Sydenham, E.W., Shephard, G. S., Gelderblom, W.C.A., and Nieuwenhuis, J.J. 1991.
Survey of fumonisin production by Fusarium species. Appl. Environ. Microbiol. 57: 1089-1093.

Tylkowska, k., Bagniewska-Zadworna, A., Grabarkiewicz-szczęsna, J., Szopinska, D., Dorna, H. and Zenkteler, E. 2008. Histopathology of Daucus carota L. root cells treated with toxic metabolites produced by Alternaria radicina and $A$. alternata. Acta Biologica Cracoviensia Series Botanica 50/1: 27-34.

Var, I., Erginkaya, Z., Kabak, B. 2011. Inhibition of ochratoxin A production of Aspergillus carbonarius by yeast species .Czech J. Food Sci., 29: 291297.

Vernon, L.P. and G.R. Seely, 1966. The chlorophylls.Academic Press, New York, London.

Vesonder, R.F., Lebeda, D.P. and Peterson, R.E., 1992. Phytotoxic activity of selected water-soluble metabolites of Fusarium against Lemma minor L. (Duckweed). Mycopathologia, 118: 185-189.

Vesonder, R. F., Peterson, R., Plattner, R., and Weisleder, D.1990. Fumonisin B1 isolation from com culture, and purification by high performance liquid chromatography. Mycotoxin Res. 6: 8588.

Wakulinski, W. 1989. Phytotoxicity of the secondary metabolites of fungi causing wheat head fusariosis (head blight). Acta. Physiol. Plant 11:301-306.

Yates, I.E., Meredith, F., Smart, W., Bacon, C.W., Jaworski, A.J., 1999. Trichoderma viride suppresses fumonisin B1 production by Fusarium moniliforme. J. Food Prot. 62: 1326-1332. 


\section{ARABIC SUMMARY}

\section{الكبح الحيوي لإتتاج السم الفطري فيومناسين ب1 ومردود سميته النباتية على النمو والتراكيب الدقيقة

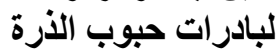

\author{
محمد عبد الله العبود \\ قسم الأحياء ـ كلية العلوم- جامعة جازان ـ المملكة العربية السعودية
}

السموم الفطرية تلعب دوراً مهماً في تلف الحبوب والبذور الزرباعبة واعبة وعندما تغزوا الفطريات المنتجة

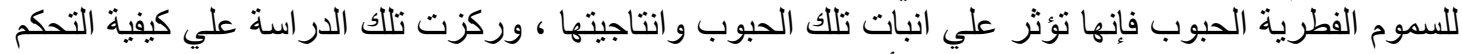

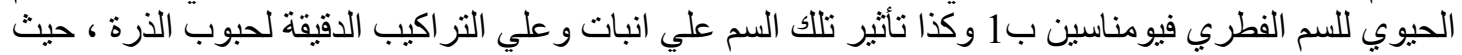

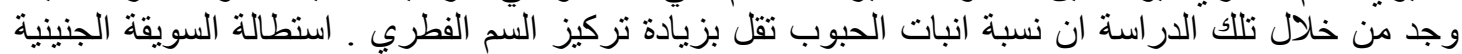

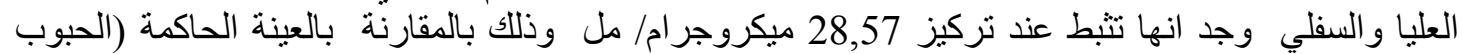

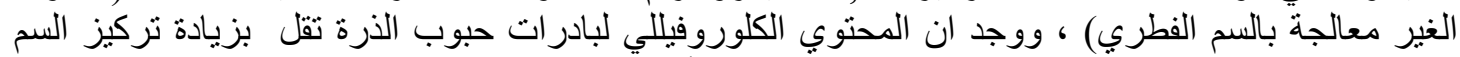

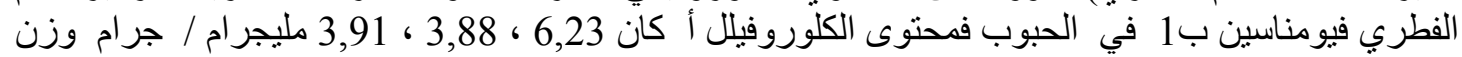
طري عند تركيز سم فطري

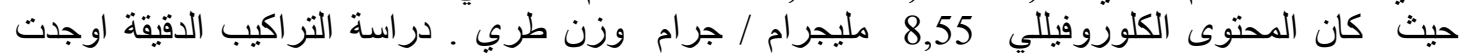

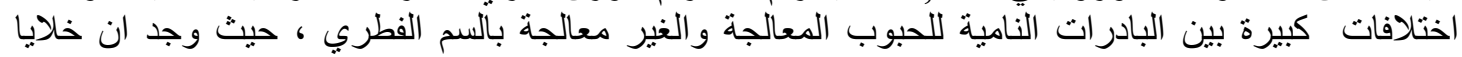

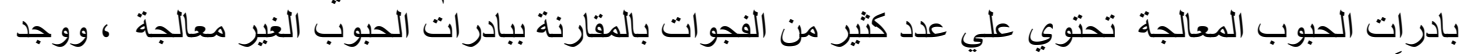

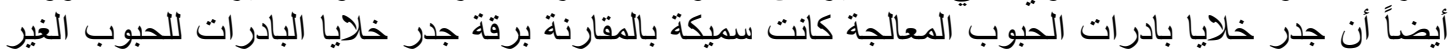

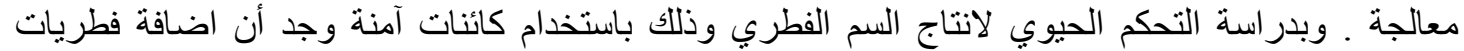

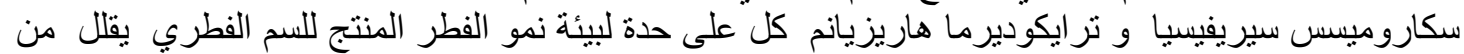

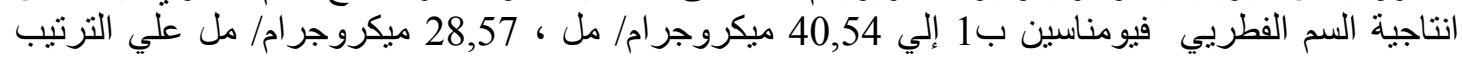

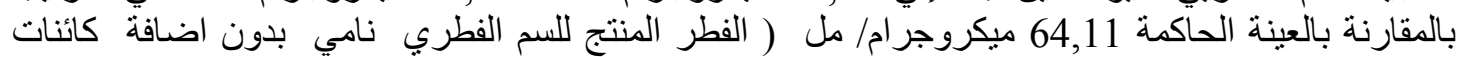

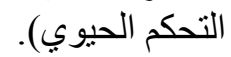

